terials, and ISO have therefore given since 1966 "two procedures" for calculating VI, one for values between 0 and 100 and, if calculation should indicate a higher value, another one for values above 100 .

Professor Dowson explains in his introductory chapter the chronological "Structure of the book", which is divided into 11 chapters, and his belief in "the wisdom of the 50-year rule", in connection with chapter 11 which has the heading: "Towards tribology: 1925 - the present". The "50-year rule" is Professor Dowson's own variation on someone else's comment that ". . . a wise historian usually stops $20-30$ years before his own time, because he cannot see the wood for the trees; the so-called thirty-year rule". The book has an appendix of 25 biographical sketches which were modelled on a book by one F. R. Archibald.

The book is remarkably free from misprints. There are the odd ones, but they are few and far between, although it is a little startling to find on p443, for instance, $-11.8^{\circ} \mathrm{C}$ as the conversion of $0{ }^{\circ} \mathrm{F}$, when the right figure of $-17.8^{\circ} \mathrm{C}$ is given 5 lines further down; that $121.1^{\circ} \mathrm{F}$ is given on $\mathrm{p} 30$ instead of $119.1^{\circ} \mathrm{F}$ as the conversion of $49.5^{\circ} \mathrm{C}$ is less easily explained; nor that 0.001 $\mathrm{oz}$ is said to be equal to $0.038 \mathrm{~g}$, whichever kind of ounce it may be. But these are details. What is disturbing are the many mistakes both in the body of the text and in the "chronological tables".
This is not the time and place to list them all. A few randomly chosen examples must suffice here. Lord Rutherford discovered the atomic nucleus in 1911. In 1919 has great achievement was the 'splitting of the atom'. $\mathrm{He}$ coined the name 'proton' for the positive hydrogen ion because, before the discovery of the neutron in 1932, he considered protons and electrons to be the elementary particles of the atomic nucleus. C. T. R. Wilson's cloud chamber dates from 1897; and 1926 , not 1924, is the date for Schrödinger's wave mechanics. The name of the discoverer of X-rays was Wilhelm Conrad Röntgen and not "Wilhelm von Röntgen". Sir William Hardy and Philip Bowden were members of the Senior Common Room of the same Cambridge College, Gonville and Caius.

The chronological tables are not without their own mysteries. In the juxtaposition of "Political and social events", "General, technical and scientific developments", and "Tribology", one wonders why the "Tribology" column was chosen to record such events as Henry Deterding assuming "control of Royal Dutch Company", the "merger between Royal Dutch and Shell", and the move of the Timken Company to Canton, Ohio.

Robert Schnurmann is Honorary Research Fellow in the Department of Chemical Engineering at the University of Birmingham, UK.

\section{Bourgeois chemist}

\section{Colin A. Russell}

Gay-Lussac: Scientist and Bourgeois. By Maurice P. Crosland. Pp. 333. (Cambridge University Press: Cambridge, 1978.) $£ 15$.

DECEMBER, 1978, was a busy one for chemical historians. The bicentenary celebrations of Humphry Davy's birth were followed by similar festivities in honour of the French chemist, Joseph Louis Gay-Lussac. Both men were born in December, 1778, though in the country of his birth Davy is much better known. Although equally distinguished for his chemical work, GayLussac has had to wait until his bicentenary for a full length biographical treatment in English. The urgent need for such a book has now been met by the timely appearance of this study by Professor Maurice Crosland.

To most modern chemists, GayLussac is merely a name associated with two or at the most three notable achievements, the best known of which is his Law of Combining Volumes (1808), asserting a simple ratio between volumes of combining gases and their products (if gaseous). He has also been associated with the law connecting gaseous volume with temperature, though more frequently this is referred to as "Charles' Law"; in fact Gay-Lussac was the first to publish (1802), but his experiments were based on earlier work by J. A. C. Charles. Thirdly, chemists will recall the "GayLussac tower" as part of the lead chamber process for making sulphuric acid, being a device for recovering nitrogen oxides from the effluent gas. The last Gay-Lussac tower that I know of in this country disappeared when the final lead chamber plant was dismantled about four years ago, so a further association with Gay-Lussac will be lost to future chemists.

However, as Crosland has been at pains to show, Gay-Lussac is worthy of commemoration for much more than this. His Law of Gaseous Volumes not only provided the foundation on which Avogadro and Cannizzaro were later to build their own theoretical structures; it seems that it confirmed to its
Your Professional Library... What's Missing?

\section{Biopolymers}

0006-3525

An International Journal of Research on Biological Molecules

Editor: Murray Goodman

Original research papers on the physical chemistry, organic chemistry and biophysics of biological macromolecules. Covers monomers, oligomers, and molecules which interact with biopolymers.

Volume 18, Monthly $\$ 242.00$

Outside U.S. add $\$ 18.00$ for postage and handling.

\section{Biotechnology and Bioengineering}

Editor: Elmer L. Gaden, Jr.

An international forum for original research on all aspects of biochemical and microbial technology, including products, process development and design, and equipment.

Volume 21, Monthly, plus Symposium Computer Applications in Fermentation Technology $\$ 140.00$

Outside U.S. add $\$ 16.00$ for postage and handling.

\section{Developmental}

Psychobiology

$0012-1630$

\section{Editor-in-Chief: Gilbert Meier}

Original results on physiological, environmental, genetic and behavioral functioning of humans and other animals during early stages of life. Assesses long-term developments.

Volume 12, Bimonthly $\$ 55.00$

Outside U.S. add $\$ 9.00$ for postage and handling.

\section{Journal of Biomedical $\quad 0021-9304$ Materials Research}

The Official Journal of the Society for Biomaterials and the European Society for Biomaterials

Editor-in-Chief: A. Norman Cranin

Evaluates preparation methods and use of plastics, ceramics, metals, and reprocessed animal tissue in fabrication of equipment and instrumentation used in medicine and biology.

Volume 13, Bimonthly $\$ 115.00$

Outside U.S. add $\$ 10.00$ for postage and handling.

Journal of Neurobiology 0022-3034

Editor-in-Chief: Graham Hoyle

Publishes papers covering a wide range of neuroscience. All types of organism and techniques of research are acceptable that bear upon the common theme of relating cellular events to behavior.

Volume 10, Bimonthly $\$ 60.00$

Outside U.S. add $\$ 9.00$ for postage and handling.

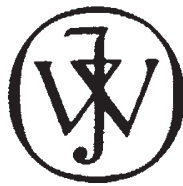

JOHN WILEY \& SOHS

605 Third Avenue New York, N.Y. 10016, U.S.A

Baffins Lane, Chichester Sussex P019 1UD, England 
discoverer the fundamental importance of volume measurements-even greater than that of weights. This conviction was nurtured by Gay-Lussac's respect for his mentors Berthollet and Laplace, whose concern for establishing general laws in science proved more attractive to their young disciple than the mere multiplication of new compounds, rather in the old natural history tradition. Oddly enough, recognition of the Law seems to have been unexpected and came (as did many other generalisations in nineteenthcentury chemistry) from studies of relatively obscure and complex phenomena, in this case the reaction between ammonia and boron trifluoride.

Associated with Gay-Lussac's work on gaseous volumes was his recognition of vapour densities as accessible and significant parameters for a compound. They were prominent in his researches on the new substance iodine. Gay-Lussac studied it extensively, concluding it to be an element similar to chlorine. He described and analysed hydrogen iodide, and discovered iodic acid, two chlorides of iodine, iodoethane, and so on. Closely related to this work was his research on cyanides. $\mathrm{He}$ obtained "prussic acid" in a pure state and prepared cyanogen for the first time. Wavering in his patriotic devotion to the memory of Lavoisier he recognised that oxygen need not always be present in acids, and to cover hydrogen halides and cyanide introduced the term "hydracid".

Nor was Gay-Lussac's concern with volumes confined to gases. In a largely industrial context he pioneered analytical methods for solutions. To have "introduced scientific rigour and established volumetric analysis as a branch of chemistry" was no mean achievement. By fitting a vertical side-tube to a graduated cylinder he devised a primitive burette that may still be occasionally encountered (though it soon turned out to be too fragile for the industrial purposes for which it was designed). He developed the pipette to something like its present form, introduced arsenic (III) as a standard for chlorimetry and made many further innovations. Other scientific work ranged from a study of fermentation to the development of lightning conductors. He studied meteorology and heat, and became one of the few Frenchmen to follow up the discovery of the Voltaic pile.

Gay-Lussac's chemical research is described in this book with verve and skill. The historian will delight in the clarity with which arguments are marshalled and the degree of historical analysis that enables his work to be seen within the context of contemporary science. Chemists will welcome a historical account that actually takes the trouble to describe the chemistry being done-an increasing rarity these days. They may cavil at a nomenclature that sometimes is neither ancient nor modern and at the use of "react" as a transitive verb, but these are small blemishes in an account that takes seriously the scientific content of GayLussac's lifework.

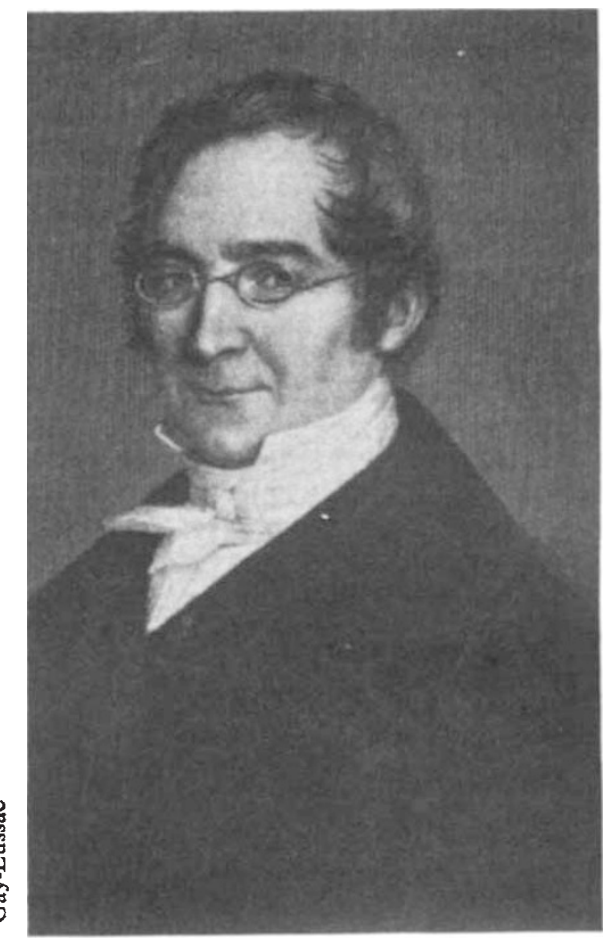

For all his obvious sympathy and respect for Gay-Lussac, the author does not portray him as either saint or hero. Rather charmingly he includes in the index an entry "Gay-Lussac, Joseph Louis, mistakes of"'! It has five references. Rightly he does not classify the rejection of atomism as a "mistake", though with hindsight it might be said to have been a pity. In GayLussac's thinking there was a streak of pre-Comtean positivism later to find fuller expression in the uncompromising anti-atomism of Berthelot. This reluctance to go beyond experimental data taken in conjunction with GayLussac's predilection for general laws suggests a tension which is never completely resolved.

Gay-Lussac is presented as a product of the middle classes determined at very least to maintain his social position. This resolve seems to have been a mainspring for his lifework, leading him to accept a plurality of academic posts, to develop his consultancy practice and to do all he could to improve his financial position. Two bar-charts illustrate that as his productivity (in terms of scientific papers) declined, so his salaried income rose to a peak. It is interesting to contemplate this recipient of a $50,000 \mathrm{Fr}$. salary insisting on patent rights for his
"Gay-Lussac tower" (and receiving 150,000 Fr. as his reward), while a selftaught plumber on Tyneside declined to patent the very device that made the Frenchman's invention a practical proposition - the "Glover tower". However some may wonder whether financial gain was all that being a "bourgeois" meant for Gay-Lussac's science. Did "bourgeois" attitudes colour the solution as well as the selection of scientific problems? Was his commitment to laws of nature (for instance) a reflection of middle-class convictions about the world? On these matters the author says little, probably for the good reason that there is little that can be said with any confidence, although he does allude to Gay-Lussac's ambivalent attitude to metrication, when "bourgeois" and "scientific" values were in conflict. He also gives a brief account of the chemist's activities as a Member of the Chamber of Deputies and his typically protectionist attitudes to industry and (especially) agriculture.

Gay-Lussac's institutional affiliations give his biography special interest for historians. He held posts in the Ecole Polytechnique, the Paris Faculty of Science, the Muséum d'Histoire Naturelle and the Ecole d'Application des Tabacs; he was a member of the National Institute and of innumerable official committees; he was joint editor of Annales de chimie et de physique; he became assay master of the Mint and was closely associated with the chemical plant of the great SaintGobain Company; above all, his early years were spent in the unofficial scientific society that met at Berthollet's home at Arceuil. Such a wealth of association gives the author an opportunity to place his subject in an institutional context of extraordinary breadth, and this he does remarkably well. Quite apart from the importance of Gay-Lussac himself, this biography gives a valuable insight into French scientific institutions of the early nineteenth century. Because of Gay-Lussac's specialist training in science, and because he subsequently earned his living through its practice, Crosland regards him as "one of the first generation of professional scientists". One wonders how useful a category of analysis this may be for an individual in early nineteenth century France, in view of the ambiguities lurking within the concept of 'professionalisation'. It may suggest false analogies between different countries or different periods. Only when such a term is rigorously defined does it become meaningful, and precisely at that moment it becomes redundant. If professionalisation is seen at the time to be a crucial issue then that of course is a different 
matter, but this does not seem to have been the casew ith Gay-Lussac.

The author declares "this biography will help give flesh and bones to one of the names found in science textbooks but, in so doing, it may also make a small contribution to a fuller understanding of the development of science". I believe that he is both over-sanguine and too modest. For me, at least, Gay-Lussac never emerges as a rounded human personality. Here and there we catch glimpses of a somewhat unbending autocrat tending to inspire respect rather than affection and himself under pressure from a financially ambitious wife. But in fact we learn little of his family life, his hobbies ("no great interest in the arts") or his religion (Enlightenment humanism). We do not even know the circumstances of his death. On the other hand, for science itself the book makes more than the "small contribution" suggested by the author. It is a solid piece of research meticulously executed with tables, footnotes, bibliographies, appendix and indexes, and is a substantial addition to our understanding of the development of chemistry at an important stage of its history. At $£ 15$ one might have expected the publishers to allow the author more illustrations than the solitary portrait that appears as the frontispiece. But we must be grateful to Gay-Lussac for having contributed so much to chemical science and to Marırice Crosland for an illuminating and soundly-constructed essay in scientific biography.

Colin A. Russell is Reader in the History of Science and Technology at the Open University, Milton Keynes, UK.

\section{Salt in}

\section{perspective}

\section{Frank Greenaway}

Neptune's Gift: A History of Common Salt. By R. P. Multhauf. Pp. 325. (Johns Hopkins University Press: Baltimore and London, 1978.) £15.75.

"SALT was known to the Ancients". So began for fifty years the lectures on the halogens given by an imperishable Oxford don. Robert Multhauf might well have begun his excellent book with the same words, conveying as they do the antiquity and continuity of his subject. A book which is primarily historical in intent, but concludes with a reference dated 1976 is, to say the least, unusual, but Multhauf is an unusual man.

He has been a man of action and saw the world before entering on a career at the Museum of History and Technology at the Smithsonian Institution which made him so well known as a leading historian of chemistry. His reach is long and his grasp firm. This work on salt has all the fluency and density of significant detail which make his earlier work The Origins of Chemistry so valuable.

The book falls into two main sections: "The Age of Culinary Salt" and "The Era of Chemical Salt". The transition is set later than would seem obvious-that is, in the nineteenth rather than the seventeenth century. Multhauf sees the food preservative role of salt as its more important feature well into the nineteenth century. Only with the expansion of the chemical industry as a whole and the concomitant expansion of large-scale manufacturing industry and long distance bulk transport does he depict salt as a key chemical raw material.

Salt is a universal necessity. Without an adequate intake, direct or indirect, normal health cannot be maintained. Yet salt is not so widespread a natural substance as might seem from its invariable association with animal life. It has to be sought by human and animal alike; so since ancient times, it has had the scarcity value which makes for trading and taxation. A history of administration could be written around salt, "an ideal article for fiscal management". There was a universal demand for it, its supply could not be left to chance and it was a fairly easy commodity to control, as was found not only in Europe but also in China and elsewhere. The salt tax, the gabelle, was hated in France and seems to have been one of the precipitating causes of the French Revolution. However, one must not take too simple a view of the historic role of salt taxes, which came and went in a very irregular way in the United States, and were much confused in Indian history by the close relationship of salt with the important saltpetre industry and trade.

The extraction of salt is an exceptional example of the stability and continuous survival of techniques which, though crude and simple, were efficient enough to render modification unnecessary for centuries. There were several methods, some of which might be found in use within a short distance of each other: evaporation of seawater by fire or solar heat, surface mining, deep mining, leaching, and so on. Simple pottery pans for boiling down brine were so customary that their fragmentary remains are good evidence of the existence of a salt industry. The largest salt industries, however, were eventually those based on deep-mined rock-salt, the demand being that of the new chemical industries. (One of several sections contributing to the wider history of technology is that dealing with drilling.)

Before salt entered its modern phase of being the raw material for sodium compounds and for chlorine, it was one of the most important means of sheer survival, being an invaluable food preservative. Lynn White has drawn attention to the importance of improved second-class protein supplies to the development of mediaeval technical vigour, but the argument can be continued: new technical improvements in salt manufacture improved the availability of meat and fish protein and so progressively helped to bring about the energising of Western Europe which ushered in what we can still usefully call Modern Times. But even greater expansion was to come as salt-mining benefited from the steam-engine and the development of iron machinery. Multhauf uses an enlightening analogy: comparing early salt-mining to an agricultural pursuit because of its often seasonal character, and showing how it was transformed into a nonseasonal industry. By 1850 the alkali industry took up about a third of British salt production. In the United States, the new meat-packing industry called for a great deal, but industrialised food preservation was much less important elsewhere. Direct culinary use levelled off about 1850 , using about half of the British total at that time. The industry expanded, however, and the second half of the book explains why. The nineteenth-century chemical industry had soda as one of its pillars with salt as the base, and the vast increase in the use of salt-derived chlorine in solvents, plastics, pesticides and the like. Multhauf points out how in the case of salt, as with so many other substances, the dominant industry is the automobile industry, using the plastics and solvents, which need chlorine, in direct manufacture, but also using very large amounts of salt as such for road treatment in winter.

The book is well produced, particularly well documented, and equipped with valuable maps and statistical tables.

Salt was known to the ancients, but, in spite of its importance, is little considered today in the perennial discussion of the effects of technology. Neptune's Gift should do much to equip us to see it in its correct perspective.

Frank Greenaway is Keeper of the Department of Chemistry at the Science Museum, London, UK. 